\title{
ANALISIS PERHITUNGAN DAN PELAPORAN PAJAK PENGHASILAN PASAL 21 PEGAWAI TETAP PADA PT. BANK RAKYAT INDONESIA KANTOR
}

\author{
Nabella L. Baguna ${ }^{1}$, Sifrid S. Pangemanan ${ }^{2}$, Treesje Runtu ${ }^{3}$ \\ 1,2,3 Jurusan Akuntansi, Fakultas Ekonomi dan Bisnis, Universitas Sam Ratulangi, Jl. Kampus Bahu, Manado, \\ 95115, Indonesia \\ E-mail : bella_bagna11@yahoo.com
}

\begin{abstract}
Income Tax Article 21 is tax payableon income which becomes the obligation of Taxpayer to pay it. Such income is in the form salaries, honoraria, allowances and other payment of any kind in respect of employment, services or activities performed by an individual Taxpayer in the country. The law used to regulate the amount of tax rqate, the procedure of payment and tax reporting is an Act No. 36 of 2008. The purpose of this study is to find out how the Calculation and Reporting Income Tax Article 21 At PT. Bank Rakyat Indonesia Branch Manado. Method of analysis used in thes research is decriptive method is to discuss of the problem by collection, decompile, calculate, compare, and explain a situation so that it can be drawn conclusions that include calculation and reporting Article 32 of permanent employees at PT. Bank Rakyat Indonesia Branch Manado. Based on the result of the study found the there is a mistake in the Calculation of Income Tax Article 21 at PT. Bank Rakyat Indonesia Branch Manado, resulting in the overpayment resulting in taxpayer incur losses.
\end{abstract}

Keywords: Accounting, Income Tax Article 21

\section{PENDAHULUAN}

Perpajakan adalah salah satu perwujudan dari peran serta warga negara sebagai wajib pajak yang secara langsung dan bersama-sama melaksanakan kewajiban perpajakan yang akan digunakan untuk membiayai segala keperluan negara dan pembangunan nasional. Bagi negara pajak merupakan sumber penerimaan penting yang akan digunakan untuk membiayai negara baik pengeluaran rutin maupun pengeluaran pembangunan. Dari segi ekonomi pajak merupakan pemindahan sumber daya dari perusahaan ke sektor publik. Pemindahan sumber daya tersebut akan mempengaruhi daya beli atau kemampuan belanja perusahaan.

Pembangunan nasional merupakan kegiatan yang berkesinambungan dengan tujuan utamanya adalah untuk meningkatkan kesejahteraan rakyat. Pembangunan ini dapat berjalan dengan lancar apabila ada sumber dana yang mendukung pelaksanaannya. Menurut APBN sumber pendapatan terbesar yaitu sektor perpajakan, meskipun masih banyak sektor lain seperti minyak dan gas bumi serta bantuan luar negeri. Hal ini dibuktikan ketika negara kita dilanda krisis, pemasukan dari sektor pajak ternyata terus meningkat dibandingkan dengan sektor lainnya.

Peran pajak bagi negara Indonesia berfungsi sebagai alat penerimaan negara dan berfungsi sebagai pengatur atau sebagai penyelaras kegiatan ekonomi pada masa yang akan datang. Fungsi pajak yang pertama inilah yang menjadikan pajak sebagai andalan pemerintah untuk menghasilkan penerimaan yang setinggitingginya dari sektor pajak.

Untuk melaksanakan kewajiban perpajakan, wajib pajak harus memahami ketentuanketentuan umum perpajakan. Salah satu ketentuan tersebut yaitu mengenai Self Assessment System. Dalam Self Assessment System seluruh proses pelaksanaan kewajiban perpajakan dimulai dari menghitung dan menetapkan besarnya pajak terutang, menyetorkan pajak terutang ke kas negara, melaporkan perhitungan dan penyetoran serta 
mempertanggungjawabkan semua kewajiban yang dilakukan oleh Wajib Pajak. Salah satu jenis pajak penghasilan yang menggunakan Withholding System yaitu Pajak Penghasilan $(\mathrm{PPh})$ pasal 21. PPh. pasal 21 merupakan pajak terutang atas penghasilan yang menjadi kewajiban wajib pajak untuk membayarnya. Penghasilan yang dimaksud berupa gaji, honorarium, tunjangan dan pembayaran lain dengan nama apapun sehubungan dengan pekerjaan, jasa atau kegiatan yang dilakukan oleh Wajib Pajak orang pribadi dalam negeri. Undang-undang yang dipakai untuk mengatur besarnya tarif pajak, tata cara pembayaran dan pelaporan pajak yaitu Undang-Undang No.36 tahun 2008 yang merupakan penyempurnaan bagi undangundang terdahulu yaitu Undang-Undang No.17 tahun 2000, yang sah diberlakukan per tanggal 1 Januari 2009.

PT. Bank Rakyat Indonesia Kantor Cabang Manado mempunyai jumlah pegawai dengan spesifikasi Pegawai Tetap dan Pegawai Tidak Tetap, sehingga memiliki potensi yang besar dalam membayar pajak khususnya Pajak Penghasilan Pasal 21. Selain itu, PT. Bank Rakyat Indonesia Kantor Cabang Manado juga berpotensi terhadap penyimpangan baik perhitungan maupun pelaporan Pajak Penghasilan yang diakibatkan oleh perbedaan pandangan atas Undang-Undang Pajak Penghasilan. Hal ini juga berpengaruh dalam pencatatan akuntansi, karena kekeliruan dalam perhitungan akan menyebabkan kesalahan dalam pencatatan akuntansi.

\section{Tujuan Penelitian}

Tujuan dari penelitian ini yaitu untuk mengetahui bagaimana Perhitungan dan Pelaporan Pajak Penghasilan Pasal 21 Pada PT. Bank Rakyat Indonesia Kantor Cabang Manado

\section{TINJAUAN PUSTAKA \\ Konsep Akuntansi}

Konsep Akuntansi Lili M. Sadeli (2012:2), mendefinisikan akuntansi adalah proses mengidentifikasikan, mengukur dan melaporkan informasi ekonomi untuk membuat pertimbangan dan mengambil keputusan yang tepat bagi pemakai informasi tersebut. Termasuk dalam definisi ini adalah keharusan bagi akuntansi untuk mengetahui lingkungan sosial ekonomi di sekitarnya. Tanpa pengetahuan tersebut, mereka tidak akan dapat mengidentifikasi dan membuat informasi yang relevan. Akuntansi juga merupakan proses pencatatan, penggolongan, pengikhtisaran dari transaksi-transaksi suatu perusahaan atau badan dalam nilai uang atau penyususan laporan keuangan dan analisisnya.

\section{Konsep Pajak}

Definisi pajak menurut Undang-Undang No. 28 tahun 2007 tentang Ketentuan Umum dan Tatacara Perpajakan pajak adalah kontribusi wajib kepada negara yang terutang oleh orang pribadi atau badan yang bersifat memaksa berdasarkan undang-undang dengan tidak mendapatkan imbalan secara langsung dan digunakan untuk keperluan negara bagi sebesarbesarnya kemakmuran rakyat. Menurut Mardiasmo (2011: 1), pajak adalah iuran rakyat kepada kas negara berdasarkan Undang-Undang (yang dapat dipaksakan) dengan tiada mendapat jasa timbalan secara langsung dan digunakan untuk keperluan negara bagi sebesarbesarnya kemakmuran rakyat.

\section{Konsep Akuntansi Pajak}

Konsep akuntansi pajak menurut Djoko Muljono (2013:2), akuntansi pajak adalah bidang akuntansi yang berkaitan dengan perhitungan perpajakan, yang mengacu pada peraturan, undang-undang dan aturan pelaksanaan perpajakan. Prinsip-prinsip yang diakui dalam akuntansi perpajakan meliputi : kesatuan akuntansi, kesinambungan, harga pertukaran 
yang objektif, konsistensi, konservatif. Fungsi akuntasi pajak adalah mengolah data kuantitatif untuk menyajikan laporan keuangan yang memuat perhitungan perpajakan yang kemudian akan digunakan sebagai pertimbangan pengambilan keputusan. Tujuan kualitatif dalam akuntansi pajak adalah : relevan, dapat dimengerti, daya uji, netral, tepat waktu, daya banding dan lengkap.

\section{Pajak Penghasilan PPh Pasal 21}

Menurut Undang-Undang Nomor 36 Tahun 2008, Pajak Penghasilan adalah pajak yang dikenakan atas penghasilan berupa gaji, upah, honorarium, tunjangan dan pembayaran lain yang diterima oleh Wajib Pajak Orang Pribadi dalam negeri sehubungan dengan pekerjaan, jasa dan kegiatan. Pajak Penghasilan merupakan pajak yang dibebankan pada penghasilan perorangan, perusahaan atau badan hukum lainnya. Pajak Penghasilan bisa diberlakukan progresif, proporsional atau regresif.

\section{Objek Pajak Penghasilan}

Objek Pajak PPh Pasal 21 Penghasilan yang dipotong PPh pasal 21 adalah :

1. Penghasilan yang diterima atau diperoleh pegawai tetap, baik berupa penghasilan yang bersifat teratur maupun tidak teratur.

2. Penghasilan yang diterima atau dperoleh penerima pensiun secara teratur berupa uang pensiun atau pengasilan sejenisnya.

3. 3. Penghasilan sehubungan dengan pemutusan hubungan kerja dan penghasilan sehubungan dengan pensiun yang diterima secara sekaligus berupa uang pesangon, uang manfaat pensiun, tunjangan hari tua atau jaminan hari tua dan pembayaran lain sejenis.

4. Penghasilan pegawai tidak tetap atau tenaga kerja lepas, berupa upah harian, upah mingguan, upah satuan, upah borongan atau upah yang dibayarkan secara bulanan.

5. Imbalan kepada bukan pegawai, antara lain berupa honorarium, komisi, fee dan imbalan sehubungan dengan pekerjan, jasa dan kegiatan yang dilakukan.

6. Imbalan kepada peserta kegiatan, antara lain berupa uang saku, uang representasi, uang rapat, honorarium, hadiah atau penghargaan dengan nama dan dalam bentuk apapun dan imbalan sejenis dengan nama apapun.

7. Penerimaan dalam bentuk natura dan/atau kenikmatan lainnya dengan nama dan dalam bentuk apapun yang diberikan oleh : a.

A. Bukan Wajib Pajak.

B. Wajib Pajak yang dineakan Pajak Penghasilan yang bersifat final, atau

C. Wajib Pajak yang dikenakan Pajak Pengahasilan berdasarkan norma penghitungan khusus.

Penghasilan sebagaimana tersebut di atas yang diterima atau diperoleh orang pribadi Subjek Pajak dalam negeri merupakan penghasilan yang dipotong Pajak Penghasilan ( $\mathrm{PPh})$ Pasal 21. Sedangkan apabila diterima atau diperoleh orang pribadi Subjek Pajak luar negeri merupakan penghasilan yang dipotong Pajak Penghasilan (PPh) Pasal 26.

\section{Tarif Pajak Penghasilan (PPh) pasal 21}

Tarif Pajak Penghasilan (PPh) Pasal 21 Direktorat Jenderal Pajak telah menerbitkan Peraturan Direktorat Jenderal Pajak Nomor PER- 31/PJ/2009 tentang pedoman teknis tata cara pemotongan, penyetoran dan pelaporan Pajak Penghasilan Pasal 21 sehubungan dengan pekerjaan, jasa dan kegiatan orang pribadi. Peraturan tersebut merupakan petunjuk pelaksanaan dari Menteri Keuangan-252/PMK.03/2008, tentang petunjuk pemotongan atas penghasilan sehubungan dengan pekerjaan, jasa dan kegiatan orang pribadi. Untuk menghitung Pajak Penghasilan Pasal 21, terlebih dahulu diketahui dasar pengenaan pajaknya. 
Untuk Wajib Pajak dalam negeri dan Badan Usaha Tetap, yang menjadi dasar pengenaan pajakya adalah Penghasilan Kena Pajak. Pajak penghasilan bagi Wajib Pajak dihitung dengan cara mengalikan Penghasilan Kena Pajak dengan tarif pajak sesuai dalam Undang-Undang Pajak Penghasilan Pasal 17 didasarkan pada tarif Progresif, yaitu tarif yang didasarkan pada lapisan Penghasilan Kena Pajak, yang artinya persentase tarif yang digunakan semakin besar jika jumlah yang dikenakan pajak semakin besar. Adapun tarif Pasal 17 Undang-Undang Pajak Penghasilan, yaitu :

Tabel 1: Daftar Tarif Pajak Penghasilan

\begin{tabular}{cll}
\hline Lapisan & \multicolumn{1}{c}{ Lapisan Penghasilan Kena Pajak } & Tarif \\
\hline I & s.d Rp 50.000.000 & $5 \%$ \\
II & Di atas Rp 50.000.000 s.d Rp 250.000.000 & $15 \%$ \\
III & Di atas Rp 250.000.000 s.d Rp 500.000.000 & $25 \%$ \\
IV & Di atas Rp 500.000.000 & $30 \%$ \\
\hline
\end{tabular}

Sumber : Undang-Undang RI No. 36 Tahun 2008

Penghasilan Tidak Kena Pajak (PTKP) Besarnya tarif Penghasilan Tidak Kena Pajak (PTKP) terhitung 1 Januari 2015 Berlaku sebagai berikut :

Tabel 2 : Tarif Penghasilan Tidak Kena Pajak (PTKP)

\begin{tabular}{clrc}
\hline No. & Uraian & Setahun (Rp) & Sebulan (Rp) \\
\hline I & Untuk Wajib Pajak Orang Pribadi & $54.000 .000,-$ & 4.500 .000 \\
II & Tambahan untuk pegawai yang kawin & $4.500 .000,-$ & 375.000 \\
III & Tambahan setiap anggota keluarga & $4.500 .000,-$ & 375.000 \\
& sedarah dan semenda dalam garis & & \\
& keturunan lurus serta anak angkat & & \\
& yang menjadi tanggungan sepenuhnya & & \\
& paling banyak 3 orang untuk setiap & & \\
& keluarga & & \\
IV & Tambahan untuk seorang istri & $54.000 .000,-$ & 4.500 .000 \\
& yang penghasilannya digabung dengan & & \\
& penghasilan suami & & \\
\hline
\end{tabular}

Sumber : Peraturan Menteri Keuangan No. 101/PMK/.010/2016

\section{METODE PENELITIAN}

\section{Jenis dan sumber data}

Jenis penelitian yang dilakukan adalah studi kasus, penelitian yang dilakukan terhadap suatu perusahaan/instansi. Penelitian ini dilakukan terhadap objek tertentu disertai dengan pengumpulan data selama periode tertentu, kemudian data tersebut dievaluasi sehingga dapat memberikan kesimpulan yang cukup jelas atas objek yang diteliti.

\section{Sampel dan teknik pengambilan sampel}

Sampel dan teknik pengambilan sampel dalam penelitian ini, yaitu :

1. Data Primer, yaitu data yang diperoleh langsung oleh penulis dari objek penelitian dengan cara wawancara dan data yang diambil dari perusahaan seperti daftar penghasilan pegawai tetap dan perhitungan Pajak Penghasilan Pasal 21.

2. Data Sekunder, yaitu data yang berasal dari sumber atau pengamatan lain. Contohnya : buku-buku literatur yang digunakan sebagai acuan, jurnal penelitian, Undang-Undang dan peraturan tentang Pajak Pengahasilan (PPh) Pasal 21, serta data pendukung lainnya. 


\section{Metode analisis}

Jenis data yang digunakan dalam penelitian ini, yaitu Data Kuantitatif yaitu data yang disajikan dalam bentuk angka-angka atau bilangan yang dapat dihitung dan dapat dibandingkan dari satu data dengan data yang lainnya. Data-data tersebut berupa daftar penghasilan pegawai tetap dan perhitungan Pajak Penghasilan (PPh) Pasal 21.

Penelitian ini dilakukan dengan menggunakan data pada PT. Bank Rakyat Indonesia Kantor Cabang Manado. Banyaknya jumlah pegawai dan lebih dari satu jenis pegawai yang bekerja di perusahaan memunculkan kompleksitas pelaksanaan pemotongan PPh Pasal 21 yang menarik untuk dikaji lebih mendalam khususnya untuk pegawai tetap. Hal yang menarik dalam praktek penghitungan PPh Pasal 21 adalah adanya kemungkinan lebih bayar atau kurang bayar untuk penghitungan secara individual atau penghitungan pajak yang harus dipotong dari tiap pegawai atau orang pribadi penerima penghasilan atas pekerjaan, jasa dan kegiatan. Dalam penghitungan pajak akhir tahun, pemberi kerja akan memperhitungkan kembali jumlah pajak yang terlalu besar dipotong kepada pegawai atau menambah jumlah yang harus dipotong. Kondisi lebih bayar atau kurang bayar ini pada umumnya disebabkan oleh fluktuasi besaran penghasilan teratur dan tambahan penghasilan tidak teratur di dalam tahun pajak. Perbedaan penafsiran atas peraturan menyebabkan adanya perbedaan cara penghitungan $\mathrm{PPh}$ Pasal 21 yang dilakukan oleh pemberi kerja.

\section{Metode Analisis Data}

Metode analisis data yang digunakan dalam penelitian ini adalah metode deskriptif, yaitu membahas masalah dengan cara mengumpulkan, menguraikan, menghitung dan membandingkan suatu keadaan serta menjelaskan suatu keadaan sehingga dapat ditarik kesimpulan yang meliputi Perhitungan Pajak Penghasilan (PPh) Pasal 21 pada pegawai tetap di PT. Bank Rakyat Indonesia Kantor Cabang Manado.

\section{HASIL ANALISIS DAN PEMBAHASAN}

\section{Hasil analisis}

Saat ini PT. Bank Rakyat Indonesia Kantor Cabang Manado memiliki 153 karyawan dengan mengklasifikasikan karyawan ke dalam tiga kelompok, yaitu : Pegawai Tetap, Pegawai Tidak Tetap dan Pegawai Kontrak Pihak Ketiga. Untuk pegawai tidak tetap perusahaan memperkerjakan mereka berdasarkan sistem kontrak, dengan masa kontrak selama dua tahun.

Untuk menjaga kerahasiaan pegawai tetap pada PT. Bank Rakyat Indonesia Kantor Cabang Manado, maka nama pegawai diberi simbol dalam bentuk huruf. Dalam penelitian ini dibatasi pada $\mathrm{PPh}$ Pasal 21 atas penghasilan pegawai tetap dan digunakan hanya 10 pegawai sebagai sampel. Selama tahun 2016 tidak terjadi kenaikan gaji. Untuk menghitung PPh Pasal 21 atas penghasilan Pegawai Tetap pada PT. Bank Rakyat Indonesia Kantor Cabang Manado tahun 2016, maka dapat menggunakan daftar Penghasilan sebagai berikut:

Tabel 4.1 : Daftar Penghasilan Pegawai Tetap Bank Rakyat Indonesia Kantor Cabang Manado Tahun 2016

\begin{tabular}{|c|c|c|c|c|c|}
\hline No. & $\begin{array}{c}\text { Nama } \\
\text { Pegawai } \\
\text { Tetap }\end{array}$ & $\begin{array}{c}\text { Jenis } \\
\text { Kelamin }\end{array}$ & Status & $\begin{array}{c}\text { Penghasilan } \\
\text { per bulan }\end{array}$ & $\begin{array}{c}\text { Penghasilan } \\
\text { yang } \\
\text { disetahunkan }\end{array}$ \\
\hline 1. & $\mathrm{~A}$ & $\mathrm{~L}$ & $\mathrm{~K} / 2$ & $\mathrm{Rp} 15.240 .000$ & $\mathrm{Rp} 182.880 .000$ \\
\hline 2. & $\mathrm{~B}$ & $\mathrm{~L}$ & $\mathrm{~K} / 0$ & $\mathrm{Rp} 12.166 .000$ & $\mathrm{Rp} 145.992 .000$ \\
\hline
\end{tabular}




\begin{tabular}{|c|c|c|c|c|c|}
\hline 3. & $\mathrm{C}$ & $\mathrm{L}$ & TK & $\operatorname{Rp} 9.807 .000$ & Rp 117.684 .000 \\
\hline 4. & $\mathrm{D}$ & $\mathrm{L}$ & TK & $\operatorname{Rp} 8.627 .000$ & $\operatorname{Rp} 103.524 .000$ \\
\hline 5. & $E$ & $\mathrm{~L}$ & $\mathrm{~K} / 1$ & $\operatorname{Rp} 6.653 .000$ & Rp 79.836.000 \\
\hline 6. & $\mathrm{~F}$ & $\mathrm{P}$ & $\mathrm{K} / 0$ & Rp 11.571 .000 & $\operatorname{Rp} 138.852 .000$ \\
\hline 7. & $\mathrm{G}$ & $\mathrm{P}$ & $\mathrm{K} / 1$ & $\operatorname{Rp} 9.234 .000$ & $\operatorname{Rp} 110.808 .000$ \\
\hline 8. & $\mathrm{H}$ & $\mathrm{P}$ & TK & Rp. 9.701.000 & $\operatorname{Rp} 116.412 .000$ \\
\hline 9. & $\mathrm{I}$ & $\mathrm{P}$ & TK & $\operatorname{Rp} 8.645 .000$ & $\operatorname{Rp} 103.740 .000$ \\
\hline 10. & $\overline{\mathrm{J}}$ & $\mathrm{P}$ & TK & $\operatorname{Rp} 7.811 .000$ & $\mathrm{Rp} 93.732 .000$ \\
\hline
\end{tabular}

Sumber : Bank Rakyat Indonesia Kantor Cabang Manado 2017

Berdasarkan daftar penghasilan pada tabel 4, maka dapat dihitung PPh Pasal 21 per bulan untuk pegawai tetap A sebagai berikut :

Penghasilan setahun

Incentive $(10 \% \times \mathrm{Rp} 182.880 .000,-)$

$=\operatorname{Rp} 182.880 .000,-$

$=\mathrm{Rp} \quad 18.288 .000,-$

Jumlah Penghasilan Bruto

$=\operatorname{Rp} 201.168 .000,-$

Pengurang Penghasilan :

PTKP setahun

Untuk Wajib Pajak sendiri $\quad=$ Rp 54.000.000,-

Tambahan Wajib Pajak Kawin $\quad=R p \quad 4.500 .000,-$

Tambahan Anak $(2$ anak $\times \operatorname{Rp} 4.500 .000,-) \quad=R p$ 9.000.000,-

Penghasilan Kena Pajak (PKP)

$=(\operatorname{Rp} 67.500 .000,-)$

PPh Pasal 21 terutang :

$=\overline{\operatorname{Rp~133.688.000,}}$ -

Lapisan I $=5 \% \times$ Rp. 50.000.000,- $=$ Rp. 2.500.000,-

Lapisan II =15\% $\times$ Rp. 83.668.000,- $\quad=$ Rp.12.550.200,- +

$=$ Rp.15.050.200,-

PPh Pasal 21 sebulan = Rp 15.050.200: 12 = Rp. 1.254.183,-

Maka, jurnal akuntansi untuk pegawai tetap A adalah sebagai berikut :

Biaya Gaji

Hutang PPh Pasal 21

Kas
Rp. 15.240.000,-

Rp. 1.254.183,-

Rp. 13.985.817,-

Dan pada saat akan disetorkan ke kas negara, jurnal dicatat sebagai berikut :

Hutang PPh Pasal 21

Kas
Rp. 1.254.183,-

Rp. 1.254.183,-

Pencatatan ayat jurnal di atas adalah pencatatan terhadap Pajak Penghasilan Pasal 21 yang telah dipotong dan disetorkan oleh pemberi kerja atas penghasilan yang diterima atau diperoleh sehubungan dengan pekerjaan dari satu pemberi kerja yang merupakan pelunasan pajak yang terutang untuk tahun pajak yang bersangkutan. 


\section{Pembahasan}

Perusahaan dalam hal ini PT. Bank Rakyat Indonesia Kantor. Cabang Manado mengimplementasikan perhitungan $\mathrm{PPh}$ Pasal 21 terhadap Penghasilan pegawai tetap sesuai dengan peraturan perundang-undangan, namun berdasarkan hasil penelitian, ditemukan bahwa terdapat kesalahan dalam penentuan status wajib pajak. Kesalahan tersebut diakibatkan karena kurangnya ketelitian dari manajemen dalam memperbaharui status karyawannya, setelah di wawancara dimana ada satu pegawai yang mempunyai suami/istri yang bekerja sebagai pegawai tetap dengan status 3 anak/tanggungan, namun dalam perhitungan $\mathrm{PPh}$ Pasal 21 terdaftar sebagai pegawai dengan status 2 anak. Selain itu, perusahaan juga tidak melakukan pendataan ulang terhadap status pegawai yang mengakibatkan adanya tambahan tanggungan yang dimiliki oleh karyawan. Sehingga perhitungan $\mathrm{PPh}$ Pasal 21 yang seharusnya adalah sebagai berikut :

Pegawai tetap A bekerja pada PT. Bank Rakyat Indonesia Cabang Manado dengan status sudah menikah dan memiliki 2 anak, menerima penghasilan bruto sebulan sebesar Rp 15.240.000,-. Akan tetapi setelah diteliti ternyata Pegawai A memiliki 3 orang anak, sehingga status perpajakannya yaitu Kawin anak $3(\mathrm{~K} / 3)$.

Penghasilan setahun

Incentive $(10 \% \times \mathrm{Rp} 182.880 .000,-)$

Jumlah Penghasilan Bruto

$=\mathrm{Rp} 182.880 .000,-$

$=\mathrm{Rp} \quad 18.288 .000,-$

Pengurang Penghasilan :

$=\mathrm{Rp} \mathrm{201.168.000,-}$

PTKP setahun

Untuk Wajib Pajak sendiri $\quad=$ Rp 54.000.000,-

Tambahan Wajib Pajak Kawin $\quad=$ Rp 4.500.000,-

Tambahan Anak (3 anak $\times$ Rp 4.500.000,-) = Rp 13.500.000,-

Penghasilan Kena Pajak (PKP)

PPh Pasal 21 terutang :

Lapisan I = 5\% $\times$ Rp. 50.000.000,- = Rp. 2.500.000,-

Lapisan II =15\% $\times$ Rp. 79.168.000,- $=$ Rp.11.875.200,- +

PPh Pasal 21 sebulan = Rp 14.375.200: 12 = Rp. 1.197.933,-

Maka, jurnal akuntansi untuk pegawai tetap A adalah sebagai berikut :

Biaya Gaji

Hutang PPh Pasal 21

Rp. 15.240.000,-

Kas

$=$ Rp.14.375.200,-

$\frac{=(\operatorname{Rp} 72.000 .000,-)}{=\text { Rp. 129.168.000,- }}$

Rp. 1.197.933,-

Rp. 14.042.067,-

Dan pada saat akan disetorkan ke kas negara, jurnal dicatat sebagai berikut :

Hutang PPh Pasal 21

Kas

Rp. 1.197.933,-

Rp. 1.197.933,--

Dari analisa perhitungan di atas, terdapat kesalahan dalam perhitungan pajak. Perhitungan PPh Pasal 21 terhadap gaji pegawai tetap pada PT. Bank Rakyat Indonesia Cabang Manado untuk pegawai A lebih tinggi dari perhitungan aturan perpajakan, sehingga dapat merugikan pegawai yang bersangkutan

PT. Bank Rakyat Indonesia Cabang Manado kurang teliti dalam memperhatikan status pegawai A . Hal ini dapat dilihat dari tabel perbandingan berikut : 


\section{Tabel 4.3 :}

Perbandingan Perhitungan Pajak Penghasilan Pasal 21

Pegawai Tetap PT. Bank Rakyat Indonesia Cabang Manado

Sumber : Data Olahan.

\begin{tabular}{|l|l|l|l|l|}
\hline No. & $\begin{array}{l}\text { Nama } \\
\text { Pegawai } \\
\text { Tetap }\end{array}$ & $\begin{array}{l}\text { Hasil } \\
\text { Perhitungan } \\
\text { PT. BRI Cabang } \\
\text { Manado(Rp) }\end{array}$ & $\begin{array}{l}\text { Hasil } \\
\text { Perhitungan } \\
\text { Penulis (Rp) }\end{array}$ & $\begin{array}{l}\text { Kurang/ } \\
\text { Lebih Bayar } \\
\text { (Rp) }\end{array}$ \\
\hline 1. & A & $1.254 .183,-$ & $1.197 .933,-$ & $(56.250,-)$ \\
\hline 2. & B & $859.473,-$ & $859.473,-$ & - \\
\hline 3. & C & $526.488,-$ & $526.488,-$ & - \\
\hline 4. & D & $331.788,-$ & $331.788,-$ & - \\
\hline 5. & E & $178.415,-$ & $178.415,-$ & - \\
\hline 6. & F & $817.548,-$ & $817.548,-$ & - \\
\hline 7. & G & $431.943,-$ & $431.943,-$ & - \\
\hline 8. & H & $508.998,-$ & $508.998,-$ & - \\
\hline 9. & I & $334.758,-$ & $334.758,-$ & - \\
\hline 10. & J & $204.605,-$ & $204.605,-$ & - \\
\hline & & & & \\
\hline
\end{tabular}

Dari tabel di atas, dapat disimpulkan bahwa hasil perhitungan PPh Pasal 21 pada PT. Bank Rakyat Indonesia Cabang Manado tahun 2016 lebih tinggi dari aturan perpajakan. Berdasarkan hasil analisis yang dilakukan oleh penulis dengan membandingkan jumlah $\mathrm{PPh}$ Pasal 21 terutang yang seharusnya disetor dengan yang telah disetor perusahaan, maka diperoleh kewajiban PPh pasal 21 terutang untuk karyawan tetap A yang seharusnya dibayar adalah Rp 1.197.933,-. Penyebabnya yaitu karena bagian manajemen perusahaan tidak secara berkala melakukan pendataan ulang para karyawannya, sehingga data yang digunakan oleh perusahaan dalam menghitung $\mathrm{PPh}$ pasal 21 adalah data dimana karyawan pertama kali bekerja.

Jika perusahaan selama tahun pajak tidak meminta data terbaru dari para karyawan, maka jumlah Penghasilan Tidak Kena Pajak (PTKP) dari karyawan tidak sesuai dengan keadaan yang sesungguhnya. Dalam hal ini karyawan akan dirugikan, namun karena $\mathrm{PPh}$ pasal 21 terutang yang seharusnya dibayar perusahaan sebesar Rp 1.197.933,- untuk pegawai A. Sehingga terjadi selisih lebih bayar yang mengakibatkan pegawai mengalami kerugian kas sebesar Rp 56.250. Oleh sebab itu, perusahaan secara berkala harus mendata ulang setiap data diri dan status karyawan sehingga jumlah PPh pasal 21 terutang yang dibayarkan perusahaan sesuai dengan data yang sebenarnya.

\section{KESIMPULAN DAN SARAN Kesimpulan}

Berdasarkan penelitian yang telah dilakukan pada PT. Bank Rakyat Indonesia Cabang Manado dan pembahasan pada bab sebelumnya, maka kesimpulan yang dapat di ambil oleh peneliti dalam penelitian ini adalah :

1. Perhitungan Pajak Penghasilan Pasal 21 pada Bank Rakyat Indonesia Cabang Manado, belum sepenuhnya sesuai dengan peraturan perpajakan yang baru yaitu Undang-Undang Nomor 36 Tahun 2008 tentang Pajak Penghasilan.

2. PT. Bank Rakyat Indonesia Cabang Manado kurang teliti dalam memperhatikan status pegawai untuk perhitungan PPh Pasal 21 terhadap gaji pegawai tetap, 


\section{Saran}

1. Bagian administrasi akuntansi perlu memperbaharui setiap peraturan perundangan yang baru mengenai perpajakan dan mengikuti setiap sosialisasi peraturan perundangan perpajakan yang dilakukan oleh kantor pajak sehingga tidak terjadi kesalahan potong baik lebih bayar atau kurang bayar yang mengakibatkan kesalahan pembayaran gaji pegawai.

2. Perlunya pengetahuan tentang perpajakan minimal tentang pph Pasal 21 agar pegawai dapat mengecek kembali apakah potongan atas pajak yang tercantum dalam daftar gajinya telah sesuai dengan ketentuan atau tidak.

\section{DAFTAR PUSTAKA}

Departemen Keuangan Republik Indonesia Direktorat Jenderal Pajak Tahun 2008. Perbandingan Susunan Dalam Satu Naskah Undang-Undang Ketentuan Umum dan Tata Cara Perpajakan Beserta Peraturan-Peraturan Pelaksanaannya Direktorat Penyuluhan Pelayanan dan Humas.

Lumintang, Alfryo Toar. 2014. Evaluasi perhitungan pph pasal 21 pegawai negeri sipil pada dinas sosial provinsi sulawesi utara. Jurnal EMBA Vol.2 No.2 Juni 2014, Hal.926 934. Universitas Sam Ratulangi. Manado. Diakses 15 Juli 2017.

Djoko Mulyono. (2013). Panduan Brevet Pajak Pajak Penghasilan. Yogyakarta. Penerbit : Andi.

Indina, Hera Bugis. 2013. Analyze Of Tax Planning PPh 21 for Employess in PT. Semen Tonasa Tbk. Universitas Hassanudin Makassar. Diakses 22 September 2017.

Sadeli, M. Lili, (2012). Dasar-Dasar Akuntansi. Jakarta. Penerbit : PT. Bumi Aksara. Mardiasmo. (2016), Perpajakan Edisi Revisi 2016. Yogyakarta. Penerbit : Andi Peraturan Menteri Keuangan No. 101/PMK/.010/2016 Tentang Besarnya PTKP Sadeli, M. Lili, (2012). Dasar-Dasar Akuntansi. Jakarta. Penerbit : PT. Bumi Aksara. Smith dan Skousen. (2012). Akuntansi Keuangan. Yogyakarta. Penerbit : Salemba Empat. Sumarsan, Thomas. 2015. Perpajakan Indonesia Edisi 4.Indeks. Jakarta.

Sutedi, Adrian. 2008. Hukum Pajak dan Retribusi Daerah.Penerbit Ghalia Indonesia. Bogor. Trisnawati (2014), Akuntansi Perpajakan. Yogyakarta. Penerbit : Andi. Undang - Undang Perpajakan No. 36 Tahun 2008 Tentang Pajak Penghasilan Waluyo, 2010.Perpajakan Edisi Sembilan. Penerbit Edward Tanujaya. Jakarta Pantouw, Andre C. 2013. Analisis Perhitungan, Penyetoran, dan Pelaporan Pajak Penghasilan 21 pada Tumah Sakit Umum GMIM Bethesda Tomohon. Universitas Sam Ratulangi. Manado. Diakses 29 Agustus 2017. 